\title{
Perspectives of lecturers' beliefs on integrating information communication technology into e-learning system
}

\author{
Duong Diem Chau ${ }^{1 *}$ \\ ${ }^{1}$ Ho Chi Minh City Open University, Vietnam \\ *Corresponding author: chau.dd@ ou.edu.vn
}

\begin{tabular}{|c|c|}
\hline ARTICLE INFO & ABSTRACT \\
\hline $\begin{array}{l}\text { DOI:10.46223/HCMCOUJS. } \\
\text { soci.en.9.1.268.2019 }\end{array}$ & $\begin{array}{l}\text { This study aims to explore how lecturers' perceptions } \\
\text { about technology integration into online teaching and learning } \\
\text { differ depending on their differences in age, gender, teaching } \\
\text { experience and IT level in the context of the e-learning system } \\
\text { of Ho Chi Minh City Open University. An online questionnaire }\end{array}$ \\
\hline Received: June $19^{\text {th }}, 2019$ & $\begin{array}{l}\text { was delivered to individual emails of } 101 \text { lecturers operating at } \\
\text { least one online subject. The results showed all the university }\end{array}$ \\
\hline Revised: July $5^{\text {th }}, 2019$ & online lecturers strongly consent that computers outweigh \\
\hline Accepted: July $17^{\text {th }}, 2019$ & $\begin{array}{l}\text { traditional face-to-face teaching methods. Nevertheless, } \\
\text { insufficient guidance on how to properly and productively } \\
\text { combine IT into lectures is their greatest concern. Next, } \\
\text { teaching seniority and gender - two personal attributes - are so } \\
\text { useful indicators for selecting most appropriate online } \\
\text { instructors, however IT certificates. Those all intensive credit }\end{array}$ \\
\hline Keywords: & for the university management to properly build-up IT capacity \\
\hline $\begin{array}{l}\text { ICT integration, ICT related to } \\
\text { online system, ICT skills, online } \\
\text { teaching skills, technological } \\
\text { education beliefs }\end{array}$ & $\begin{array}{l}\text { for their teaching staff within their online learning system. } \\
\text { Accordingly, some useful and practical implications in starting- } \\
\text { up a technology love culture in the institutional environment } \\
\text { are proposed. }\end{array}$ \\
\hline
\end{tabular}

\section{Introduction}

Technology with computers and the Internet has been changing many aspects of social life that do not exclude education. At present, universities can hardly refrain themselves from digital learning modes. Instead, the growth of online study has been so fast that it is not a new approach in teaching and learning at all but creates a "new culture learning" (Jääskelä, 2017) where both instructors and learners are expected to establish new values, customs and perceptions for successful technology integration into their teaching and learning practices in which the teachers with their beliefs of technology integration into education are considered a key determinant. It has been observed that the teachers' age, gender, teaching experience, technical competence are the personal attributes that make their mindsets different (Kumar \& Daniel, 2016), and thus determining the success of the technology integration in any context. 
Keeping up with the latest trend of education in an era of technology, Hochiminh City Open University (HOU) has officially launched online training programs. The eLearning Center (ELO) has been established to integrate knowledge and action, beyond the limits of place and time, generations and regions. This reality necessitates rigorous research studies to reflect on and ensure the effectiveness of the system's operation. And this study is intended to make a contribution to the needed investigations into the reality of the operation of ELO at HOU by focusing on the sound understanding of its teachers whose perceptions of technology application are vital in transferring from face-to-face to e-teaching and learning mode.

\section{Literature review}

Lecturers with their technological competence have determined how achievable their universities' ICT implementation can be in this digital education (Zare-ee, 2011). As a matter of fact, the ability to integrate technology into lectures has been proposed a $21^{\text {st }}$ century skill of lecturers which is advisably promoted by universities in a careful way (Adnan, 2017). ICT ability has become a vital element of professional development in a lecturer's lifelong career (Alt, 2018; Kubrický \& Č́stková, 2015) that Valtonen et al. (2014) suggest being equipped at the beginning of a teaching job. Copriady (2015) asserts that a teacher only reaches his professionalism level by constantly overcoming challenges arising from new technologies. Teaching in a digital environment is clarified by Claro et al. (2018) with three components: knowledge, skill and attitudes of a teacher's capability of designing, organizing, guiding and evaluating learners' study activities. Lack of ICT skills could be blamed for teachers' unwillingness of using technology and demotivation of participating in the online teaching mode (Dintoe, 2018; Jääskelä, Häkkinen, \& Rasku-Puttonen, 2017), thus becoming a barrier in operating e-learning systems (Kumar \& Daniel, 2016; Zare-ee, 2011). Instead, a set of qualified computer skills would ease teachers accommodating with a new tendency, internetbased teaching method (Agbatogun, 2013).

In reality, teachers mostly value and appreciate technology with its advantages to their pedagogical implementations (Jääskelä et al., 2017) and research (Zare-ee, 2011). According to all the trainee teachers of University of East Anglia in Haydn and Barton's study, ICT skills are very useful to produce a qualified lecture. It, moreover, provides them with a positive background to further develop their IT capacity which in turn contributes to their success in a teaching career, rather than only satisfies school recruitment and selection criteria (2007). Besides, instructors of online courses in the research of Schmidt, Hodge, and Tschida (2013) agree that their technology experiences help them more easily approach their online learning and teaching system. In a case study of Hart (2014), the teachers under investigation confirm that technology competency makes them more productive and effective in teaching, which definitely contributes to student learning outcomes even their positions are student learning supporters in an online system. Zare-ee (2011); Azlim, Amran and Rusli (2015) report ICTs add enormous value to educational practices.

Moreover, online learners (in Hung \& Chou' research) do pronounce that it is very helpful when their instructors are able to apply a wide range of technical tools in their lectures and learning facilitation (2015). Likewise, Safar and AlKhezzi (n.d.) along with Gomez-Rey, 
Fernández-Navarro, Barbera, and Carbonero-Ruz (2018) postulate that under students' concepts, an effective online lecturer must be able to integrate ICT tools into his teaching pedagogical method thereby positively affecting their learning results. Specifically, once embedding multi-media into their lectures, lecturers enhance not only student attendance but knowledge acquirement since learners prefer typing questions to write (Jamil \& Shah, 2011). Additionally, within an online collaborative platform, students are likely to receive prompt feedback from their lecturers (Rose \& Adams, 2014). As a result, a student's GPA or grades tend to be better.

The solution that training teachers prior to assigning them an online teaching task has been unceasingly supported and discussed by a lot of scholars. Safar and AlKhezzi (n.d.), Crawford-Ferre and Wiest (2012); Hung and Chou (2015) advise faculties should train their teachers before teaching online and provide them with technical support in this paradigm that totally demands a new set of ICT skills rather than teaching face-to-face. With those training activities, intended online instructors would get to acknowledge what to expect and how to establish their online pedagogies, and be nurtured with positive attitudes towards web-based teaching (Baran, Correia, \& Thompson, 2011). Furthermore, appropriate ICT training programs would turn faculty members more self-efficacy in computer applications and increase their likeliness to use them for their jobs (John, 2015). Altogether, learning how to combine technology, content and pedagogy in the teaching is a pre-condition for using ICTs to teach (Jita, 2016) that in turn determines the effectiveness of online teaching environments (Hung \& Chou, 2015).

Nevertheless, training seems to be not a perfect way to technical skills improvement because it fails to draw out a full picture of digital technology's advantages in teaching (Gonzalez, 2013). From the prospect of Schmidt et al. (2013) equip e-teachers does not simply mean providing them with technological savvy, instead of turning them able to accommodate it into their pedagogies smoothly. Teachers after being trained still present reluctance and are challenged to move behind a lectern to a computer screen (Dintoe, 2018). In fact, it is a risk for institutions to prepare this skillset for their teaching staff as there is a gap between what a person performs in reality with what he is expected (Madsen, Thorvaldsen, \& Archard, 2018). Consequently, a new approach proposed is getting to know what lecturers perceive of ICT integration into teaching, thereby affecting powerful factors of their minds to alter their behaviors towards digital educational systems. By eighteen in-depth interviews with university teachers, González (2012) observes that lecturers' perception of their own computer expertise mainly leads them to e-learning incorporation. In detail, the higher level of their ICT competence they self-evaluate, the easier they approach online teaching and learning. From the same perspective, Zare-ee (2011) claims that in order to measure how teachers transit their role in the ICT environment, it is essential to early grasp their thinking of technology application.

The issue becomes more complex as recognizing the compatibility of technology with teaching methods varies from lecturer to lecturer due to their different personal attributes such as age, gender, teaching experience; ICT competence and preference (Kumar \& Daniel, 2016); and beliefs (Dintoe, 2018). For example, the responses of 828 Chilean teachers in a survey 
conducted in 2018 by Claro et al. teaching experience demonstrates their proficiency in the digital education system however young they are. Another situation is that John (2015) by examining the attitude towards IT adoption in the teaching progress of 261 faculty members of leading universities of Asian region affirms a significant gap in the mindsets of people under and over fifty years old. He also explores that men present more optimistic perceptions than their counterparts. This is also the finding of a previous study implemented by Jamil and Shah in 2011 with a group of 336 lecturers from eighteen private universities and eight public ones in Punjab, Pakistan. In specific, they mostly express their ideas that males tended to more rely on technology for designing their lectures than females. In contrast, 580 teachers at University of Ilorin, Nigeria refused the impact of gender on ICT utilization (Onivehu, Adegunju, Ohawuiro, \& Oyeniran, 2018). From other viewpoints, Shattuck and Anderson (2013) when examining the impact of a training course for online instructors COAT (Certificate for Online Adjunct Teaching) detect that prior teaching experience is one of the influential factors of online teaching ability. Depending on his examination of a faculty training program in University of Maryland University College, Wolf (2006) stresses on the necessity of computing skills of lecturers prior to enrolling in training for teaching online, which at least embraces competencies in using of the computer, the Internet, and online applications.

To put all in a nutshell, what influential elements relating to teachers' beliefs are key to encourage them in the process of ICT integration into e-learning has been debated case by case. Apparently, it is necessary to conduct a study for the purpose of identifying factors - almost related to mindset - that influence online instructors to adopt and diffuse the technology in the system of digital education.

\section{Methodology}

\section{Research Goal}

This study aims to explore how lecturers' perceptions about technology integration into online teaching and learning differ depending on their differences in age, gender, teaching experience and IT level in the context of the e-learning system of HOU.

\section{Instrument}

A field survey using a structured online questionnaire was conducted in order to achieve the goal of this research.

\section{Sample and Data Collection}

In this study, the population was 101 lecturers teaching at least one online subject through the e-learning system of HOU. The majority of them (91\%) were full-time faculty members of the university, two were working in its ELO and the remaining of seven were from outside organizations (other universities and companies). The survey was divided into two sections: (1) Section A: Demographic data of respondents and (2) Section B: Factors of the lecturers' perceptions of the utilization of technology in their online teaching practices. Section B was further divided into six factors with twenty-five items issued by Kihoza, Bada, and Kalegele (2016); John (2015); Lachner, Jarozka, and Nuckles (2016) and Shagrir (2015). These 
are lecturers' frequency of ICT use; comments on benefits and barriers of integrating ICT into online teaching; confidence in using technological tools in teaching; attitudes towards computer-based teaching; ability to create interaction with students by technological support. This study also considers four independent variables (gender, age, teaching experience, IT certificate) jointly contributed to the prediction of faculty members' beliefs of ICT integration in the university's online education system depending on the content of each factor.

\section{Table 1}

The five-point Likert scale used in the questionnaire

\begin{tabular}{l|l}
\hline Responses Ranks & Ranks \\
\hline Strongly Agree & 5 \\
Agree & 4 \\
Neutral & 3 \\
Disagree & 2 \\
Strongly Disagree & 1 \\
\hline
\end{tabular}

Source: The researcher's data analysis

\section{Analysis and Results}

\section{Section A. Demographic Analysis}

From the demographic section, data on lecturers' gender, age, teaching experience, teaching area and ICT level were collected. Among 101 respondents, there were 39 males and 62 females, whose ages were in the range of twenty-seven to sixty-three with an average of thirty-nine. The researcher purposely divided the participants into three age groups: under thirty-five, between thirty-five and fifty; and over fifty years old; and three teaching experience groups: below seven, from seven to twenty; and above twenty years. It is expected there is an intensive correlation between two criteria which will be tested by the following factors.

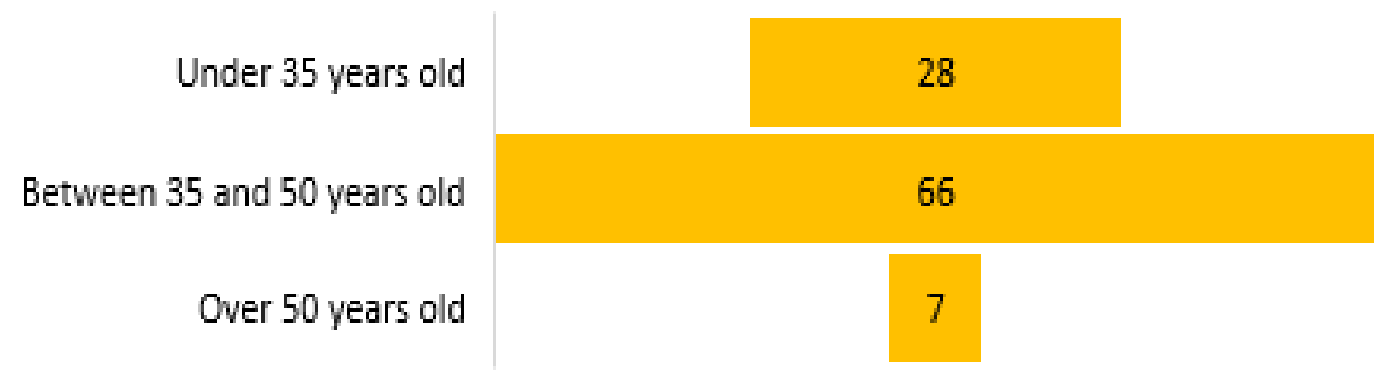

Figure 1. Respondents' age 


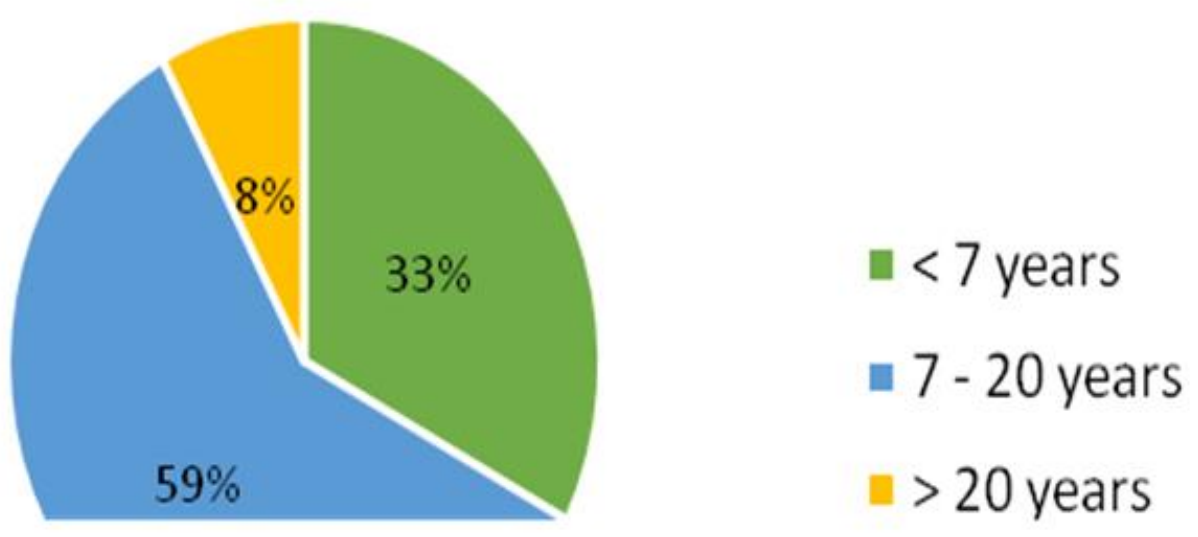

Figure 2. Respondent teaching experience

As shown in Figure 1 and Figure 2, in both age and teaching year groups, the largest were the respondents in the middle of both ranges while the smallest were the participants at the upper points.

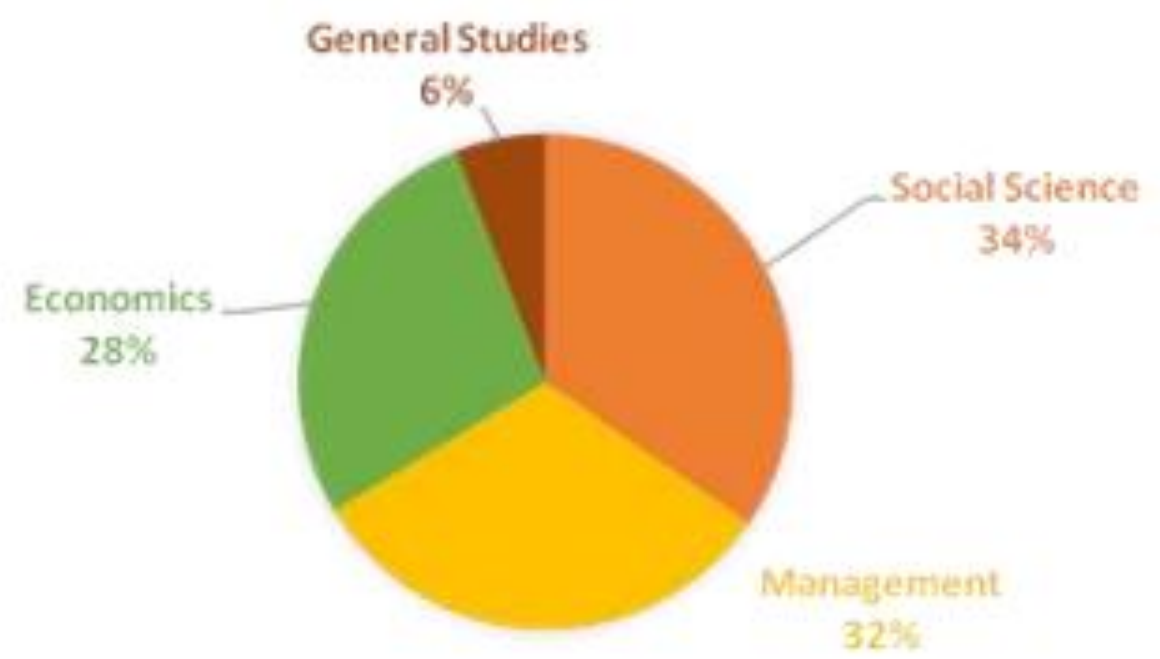

Figure 3. Persons in teaching areas

Figure 3 shows the teaching areas of respondents, 34\% of whom were from Social sciences; 32\% Management, 28\% Economics and 6\% General studies. 


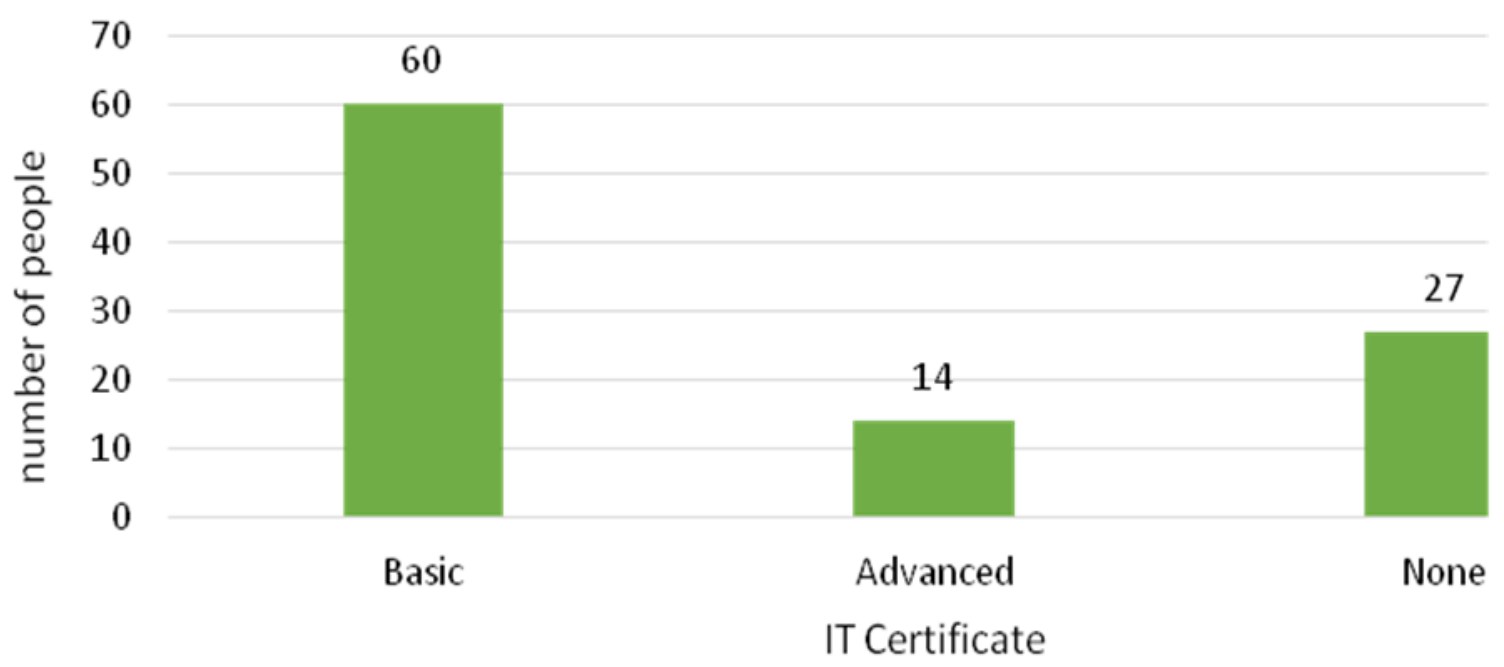

Figure 4. ICT skill level

Figure 4 presents $73.3 \%$ which held IT qualifications with 60 lecturers at fundamental and 14 at advanced level. The rest stated that they had no evidence for their ICT skills.

\section{Section B. Factors Related to Perception Analysis}

Frequency of ICT use

The survey shows that the majority of respondents (around 70\%) regardless of their ages selected Presentation Software (e.g. MS Power Point and Projector) as their most used ICT device. No one has never utilized Communication Applications such as email, computer conferencing; however, it was the second frequently used in all groups. Not surprisingly, Internet Resources (Web posts, chat rooms, discussion forums, web tools, etc.) with the "always used" option presented a minor distinction in teachers from three age groups; nonetheless, the oldest was the least with 43\%. Among four types of ICT tools listed in the survey, only Communication Applications showed a big difference between the first two groups and the last in replying to the option "always used". In particular, the number of lecturers over 50 years old was two times less than that of those under this age. Moreover, a number of teachers who applied regularly Multimedia was not only the smallest in three groups but decreased gradually to $21 \%$ to $17 \%$ to $14 \%$ when their age group moved respectively from under thirty-five to between thirty-five and fifty to over fifty years old. Multimedia was also the one for which the choice "never used" was chosen most by participants at any age.

Aligning with ages, teaching experience counted by years was the next criterion for testing how often IT devices had been applied. Logically, this had a similar result to the age standard. However, dissimilar to age, the smallest percentage (43\%) fell at the group teaching from seven to twenty years.

The statistics demonstrate the high validity of two individual attributes: age and teaching years. It is extremely consistent with the assumption that one would normally begin their first teaching career formally at his age of twenty-seven. Hence, the two criteria can be mutually replaced when applying for the following testing factors. 
The respondents at any age and with any teaching years in this research showed an outstanding level of frequency in using some ICT devices like Presentation Software, Communication Applications, Internet Resources. That university management will treasure for its e-learning system because it is believed that the more often a lecture employs technology in the teaching process, the more extensive knowledge and likely to adopt new technology he will be (Copriady, 2015). However, it is advisable to pay attention to over fifty-year-old and seven-to-twenty-teaching year educators for their accommodation of internet resources. On the other hand, multimedia is not a wise choice the online administrators should develop.

\section{Comments on ICT application into Teaching Practices}

Despite different teaching experiences, a high percentage of instructors (averagely over $75 \%$ ) admitted advantages technology has brought to the teaching and learning process once accommodated into the lecture. Furthermore, the smallest figures almost were found with over fifty teaching year lecturers, except for the statement "Use ICT that enhance students learning for a lesson" with which $100 \%$ of them agreed. Similarly, the benefits of IT integration into teaching practices were seen as slightly different between male and female teachers. Above $87 \%$ of both genders expressed high level of agreement on these positive outcomes.

On the other hand, more than half of males and females both considered institutional guidance in technology integrated into the education system the most concern which the former's statistic was $12 \%$ more than the latter's. While women supposed "Lack of focus in the curriculum on the application of ICTs" as the least barrier, their counterparts did "Teachers' lack of interest in using ICTs for teaching", which was also the one nearly $52 \%$ of female teachers disregarded as a difficulty. The widest distance in two genders' thoughts fell in the weakest reason assessed by $29 \%$ of women but that was the second biggest trouble of male teachers (49\%). Roughly half of the female answerers in contrast worried more about the Internet connection.

Based on teaching years, not enough interest and experience of teachers related ICT use as well as "Lack of focus in the curriculum on the application of ICTs" were not the main concerns of people over twenty years in lectern that oppositely threatened whoever spending less than this teaching time. In particular, the portion of teachers with less than seven-year experience stayed at a rather high figure (42\% above) for the issue whilst that with seven-totwenty-year experience was a bit smaller (below 40\%). The smallest number of the latter (28\%) chose "Teachers' lack of interest in using ICTs for teaching". On the contrary, the over twentyyear teaching instructors equally cared about Internet quality and the university's framework of ICT integration. The latter anxiety was also the most worry of the other two categories that the class of less seven-year working lecturers presented the greatest number (21/33 selects).

The online teaching staff seemingly value technology with the Internet in e-learning system though they are different in gender and teaching seniority. Nonetheless, in terms of genders, although they all find several difficulties such as ICT interest, internet connection, males and females show dissimilar degrees of these obstacles but not much. In contrast, teaching experiences do intensively affect teachers' assumption of challenges in ICT accommodation. People with the longest teaching time do not worry about a suitable way to embed technology into the curriculum, but the ones with shorter teaching experience do. 
Oppositely, younger lecturers do not consider Internet connection a problem which the older do. Regardless of gender and teaching experience, the university's framework of ICT integration presents as the most problematic.

\section{Confidence of lecturers' in using technological tools in teaching}

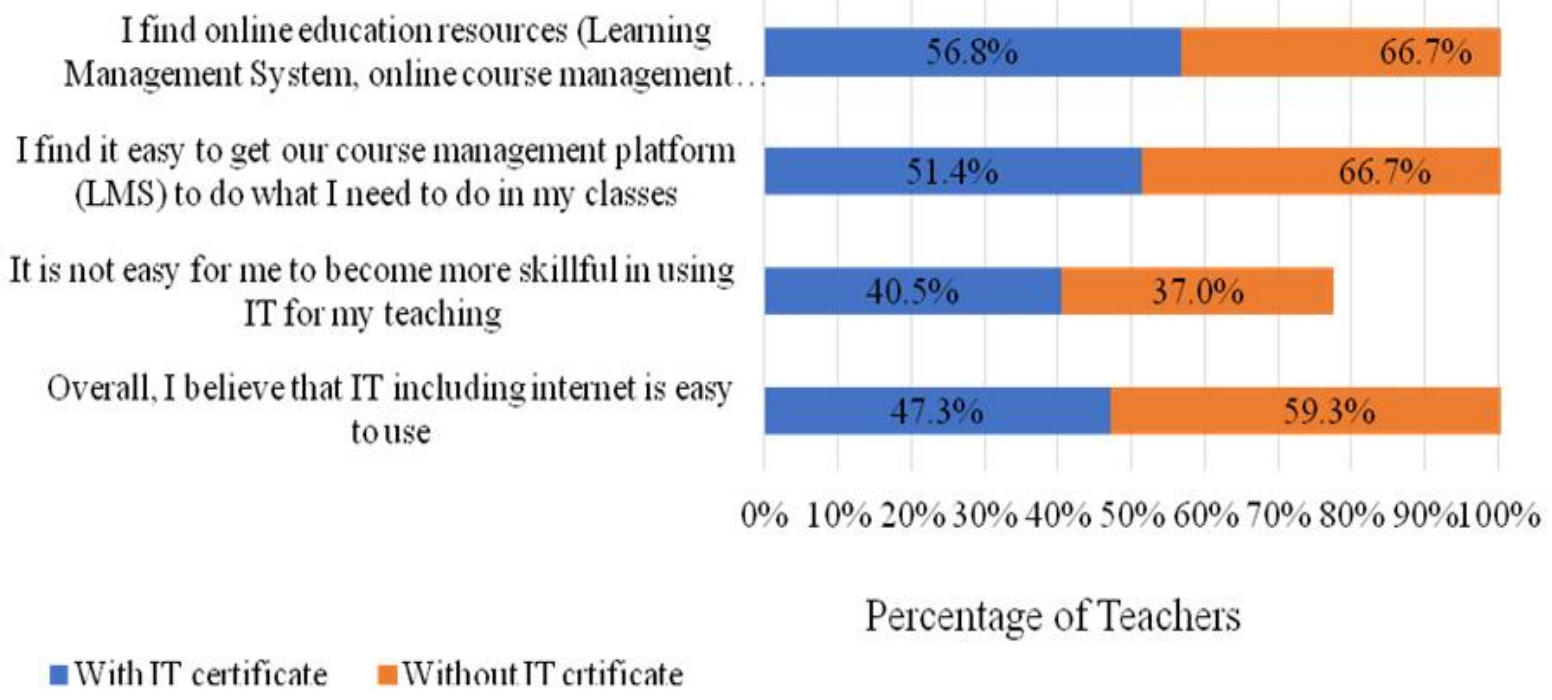

Figure 5. Confidence in ICT use

It is unexpectedly confused that more instructors who claimed they did not hold any IT certificate expressed a high level of self-efficacy in ICT application, excluding the confidence in skillfulness of using IT for teaching, about which two groups of basic and advanced technological levels were uncertain most. Among teachers holding IT qualifications, the quantity of them with advanced level feeling confident in most statements was greater than that of fundamental. Whereas the former was better self-assured at online education resources, the latter course management platform - LMS.

Teaching experience proves its positive influence on instructors' assurance of ICT applied. In fact, people with over twenty years in lectern showed the highest figures which were remarkably greater than that of ones both under seven and between seven and twenty teaching years. Between the two types of lecturers less than twenty years in teaching, there was almost no considerable distance in their confidence. Apart from the reply on 'how easy to use online resource', the number of people below seven was about $20 \%$ smaller than that from seven to twenty teaching years. In the field of controlling online resources, course management platforms, and Internet, males ascertained better than females. But the greater number of men were afraid to not easily become ICT skillful than their counterparts. Both genders were highly assured with technology accommodation (roughly $50 \%$ of each group). They all were most selfconfident at online resources (men: 64\%; women: 56.5\%), however, males were least assertive at course management platform while women at the Internet.

All in all, ICT qualifications will not be a reliable factor to acknowledge the levels of lecturers' confidence in technology usage whereas teaching experience and gender will. The more time one spends in teaching, the more confidence he displays in IT application. Nonetheless, the gap in teaching time should be taken into account because the less it is, the 
smaller difference would be found. Men in addition are nearly more self-confident than women in this area with the exception of ICT skillfulness. The former group is still reluctant to course management platform meanwhile the latter is to the Internet.

\section{Attitudes towards computer-based teaching}

Instructors with either fundamental or advanced ICT level and without IT qualifications were most preferable to encourage students using the Internet to access learning materials. High percentage of them, moreover, all appraised the effectiveness of computers as instructional tools; then admitted adoring computers in their teaching. A bit smaller (roughly 70\%) hesitated whether computers really outweighed traditional methods of instruction. There were minor gaps in those perceptions between the groups holding IT certificate and not holding, where the volume of not holdings was seen bigger. The belief on "students and teachers should use computers in all subject matters" received the least supported by teachers possessing advanced ICT level (64\%), meanwhile, a sound statistic (75\%) of ones having low level agreed with it. And non-ICT qualification people $(81.5 \%)$ still raised high recommendation of it.

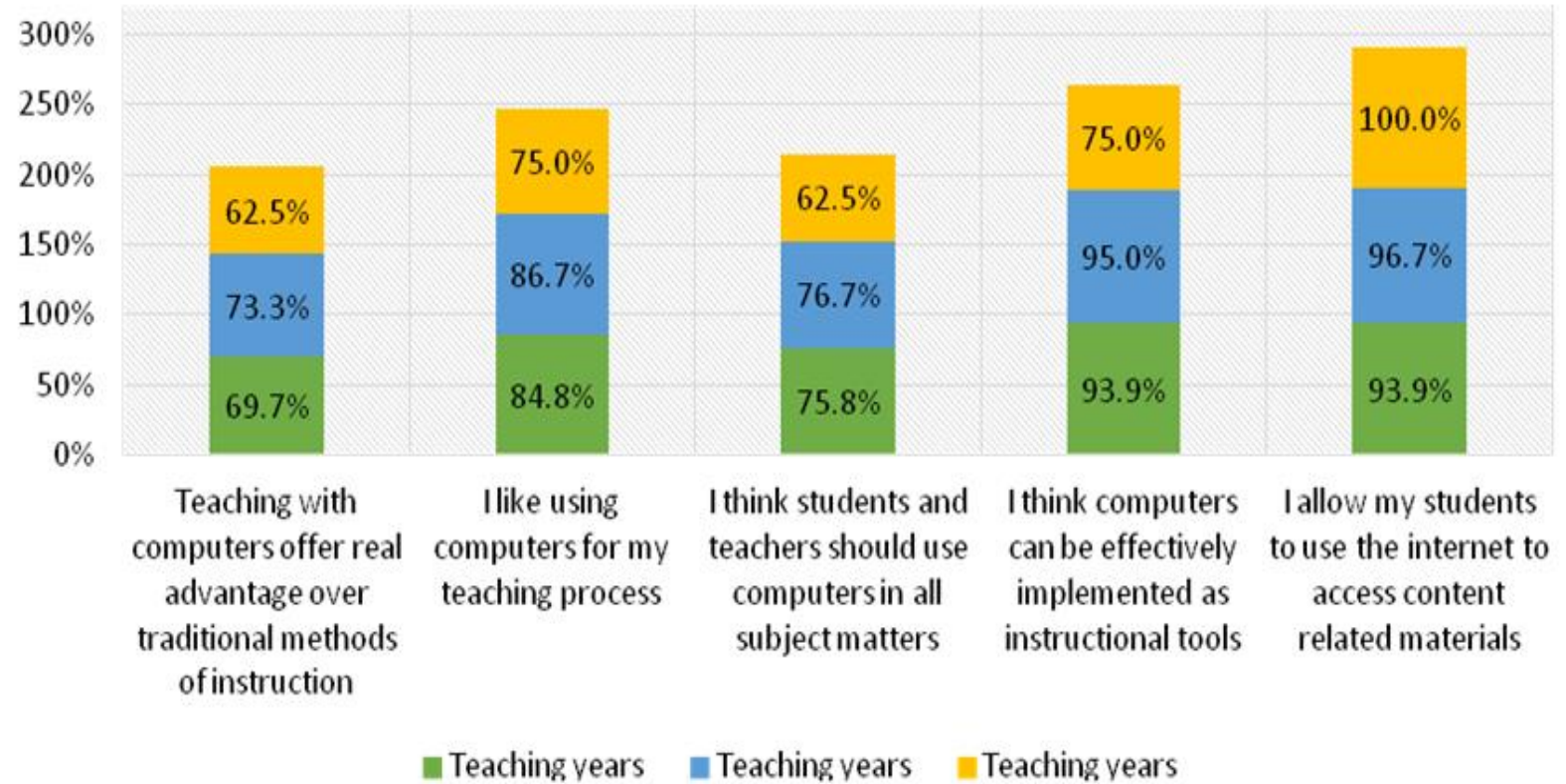

Figure 6. Positive attitude towards computer-based learning

As seen in the chart, internet access for learning materials was encouraged by the largest proportion of respondents regardless of teaching time. More teachers spending over twenty years at schools less liked using and believed in computer function as a highly productive tool in subject delivery than the rest. Indeed, $93.9 \%$ of lecturers below seven teaching years and $95 \%$ between seven and twenty years regarded computers as their effective instructional tools meanwhile $75 \%$ with over twenty years did so. Likewise, around $85 \%$ of two former groups were fond of using computers in teaching compared to the latter with $10 \%$ smaller. Three categories in working years revealed small differences in their assumptions on the computer advantages over traditional teaching mode and its appropriateness for lecturing all subjects.

Similarly, 'basing on Internet for materials' was the most strongly agreed by both genders. They all were next convinced by computer effectiveness in teaching, following with their favor in the computer where the female group presented with a higher percentage. The 
quantity of women kept larger on the opinion of computers defeating face-to-face training. The reverse was true in the opinion on computer likely applied in all course.

Again, there is no positive correlation between IT certificate with attitudes towards computer system. Some identifications on the other hand are proposed according to teaching seniority and gender. Above all, Internet access for materials is most supported in all groups. Next, these teachers admit that the computer offers real advantages over traditional methods of instruction. Nevertheless, 'like to use computer and evaluate it as an instructional tool' are less favored by more experienced lecturers. And male instructors do not totally think computers should be applied in delivering all subjects. Overall, this result supports fifty-five academic staff's viewpoints in the study of Kumar and Daniel (2016) that lessons driven technology have enhanced learners' task performance as well as encouraged their creativity.

\section{Interaction behavior supported by technology}

Teachers in spite of ICT qualifications do not concur with the idea that they need to be always available to students. The smallest number was found in the basic ICT level group. Additionally, whether possessing an IT certificate or not, over $90 \%$ accepted that technological devices helped to put themselves in their students' positions. Besides that, the absolute quantity of participants with advanced ICT level pronounced that students found it easy to contact when needed and demonstrating their caring about student understanding through technological assistance. Those areas were, in contrast, indicated by roughly $20 \%$ less volume of teachers having basic ICT grade or without any degree.

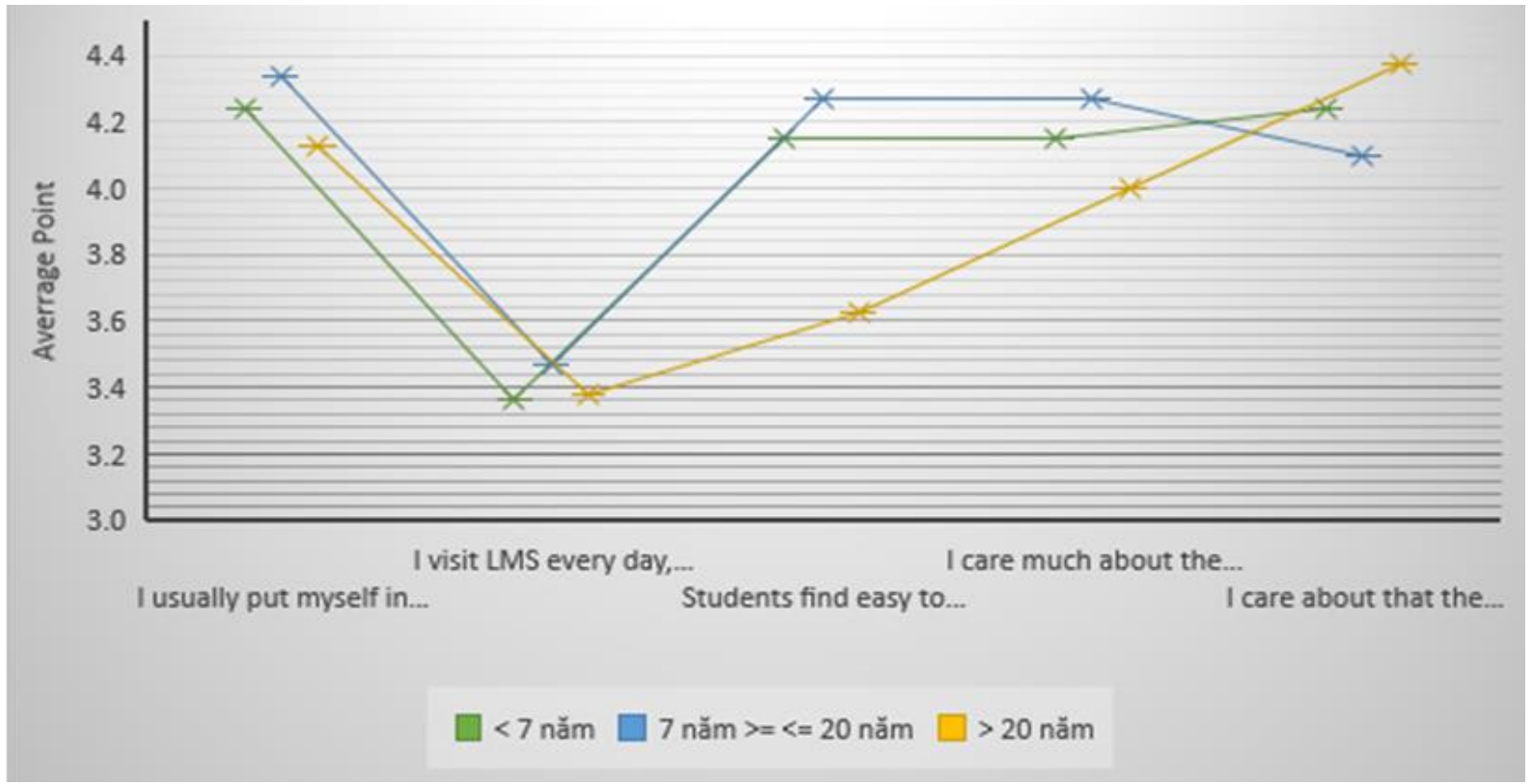

Figure 7. Teacher-student interaction supported by technology

The average point of answers from three different teaching year groups moved from slightly below 3.4 to 4.4 . Those points were not so distinguished in the exception of the issue "how easy students find to contact lecturers", in which teachers with over twenty-year experience placed 3.6 whereas the middle group did 4.3 which was moderately higher than the under seven group. However, all of them gave the least grade (around 3.3) for 'often availability 
on LMS', which also were agreed by the smallest number of each group from below seven to above twenty, $45 \%, 47 \%$ and $37 \%$ respectively. In the assessment of 'technology eases students contacting to instructors', the percentage of respondents with teaching time between seven and twenty years (90\%) nearly doubled that over twenty years and was 10\% greater than that under seven years. Likewise, a big distance (35\%) was explored between the second and the last group in statistics of their 'commitment to serve students individually'. Despite their teaching seniority, respondents thoroughly appreciated technological support on getting them close to learners and exhibited their caring for a student's lesson comprehension. Altogether, over twenty teaching seniority lecturers almost displayed the lowest figures in this field, except for the item on 'student understanding'.

Evidently, people with higher IT levels are prone to recognize how beneficial technology is to their interaction with students. But it does not mean they value the fact that ICT enhances their availability to learners, so do teachers with lower IT level or without it. When dividing lecturers into different teaching experience groups, this phenomenon is reappearing. Hence, it is safe to resume that online instructors do not consider the benefits of regular availability to students brought by ICT. Moreover, lecturers teaching more than twenty years reject the role of technology in supporting leaners' contact with them. Those also do not highly value advantages ICT could offer for student-teacher interactions. However, technology applications make them clearer on degrees of learners' lesson understanding.

\section{Discussion}

Currently, Information Communication Technology (ICT) application influences the success of lesson design (Do, Fernando, \& Marrisa, 2018). And teachers' ICT ability determines whether an educational system can meet requirements of using Information Technology (IT) at schools (Kihoza et al., 2016), especially within an online education system. Therefore, understanding how adaptable teaching staff can be and what they conceive with a university e-learning system is essential and crucial for institutional management. With these results above, the university would thank its lecturers' mindset of ICT because they conceive very positively of technology application and its benefits to their own teaching practices as well as the whole e-learning system. They strongly consent that computers outweigh traditional faceto-face teaching methods. As seen in the literature, that is the very first advantage for online education administrators since the more positive people are with ICT accommodation, the more willing and readier they become e-lecturers. In fact, Kumar and Daniel (2016) acclaim perceptions of online instructors on technology's advantages and their willingness to apply ICT as well as individual technological attributes are crucial predictors for success in process of integrating technology into teaching. The next appreciation is that school teachers almost consider the role of computer as an effective instructional tool. That will absolutely be an added value for web-based learning development. Copriady (2015) declares that the acquaintance of using computer among educators is the excellent signal for their further automatic adoption with a variety of modern technological devices and networks.

It is obvious that online teaching staff do appreciate advantages advanced technology brings into lectures but express several obstacles that need considering. Since difficulties in technological education are identified by teachers help to understand their intention towards ICT usage in addition (Agbatogun, 2013). Insufficient guidance on how to properly and 
productively combine IT into lectures is the greatest of concern. That leads to successive worry about divergence of technology integration into e-curriculum. Actually, it is annoying if every instructor follows his own way to apply IT in digital teaching process. Moreover, though Internet connection is the basement of web-based learning systems, most current institutional lecturers have raised a suspicion of its speed, stability and security. That alerts online education system operators to focus on those matters in constructing the framework for its success. Also, the university managers should be cautious to ask their teachers to utilize technological tools in online teaching activities, particularly multimedia devices. Briefly, the type of technology in internet-based learning will be successfully integrated into teaching modes once being with lecturers' technological competence and not dissociated from their pedagogical activities (Kubrický \& Č́stková, 2015). In summary, constructing a clear framework and qualified internet together with selecting proper categories of ICT for online teaching practices all are solutions to upgrade successfully the university e-learning mechanism.

Accordingly, teaching seniority and gender - two personal attributes - are so useful indicators for selecting most appropriate online instructors, however IT certificates. The survey demonstrates there is no connection between technology level with lecturers' confidence and attitudes toward ICT integration. On the contrary, teachers with greater experience likewise to men are more confident with ICT usage. In addition, elderly instructors are less convenient with Internet access while the younger feel more challenged to consolidate technology with curriculum. Men tend to hesitate more than women in the field of course management platform. That should be taken into consideration when administrators assign an online teaching task for a teacher at a stage of e-education system development progress. These individual features definitely influence the success of online teaching assignment. For instance, at the beginning of building-up an online program, it is less risky to choose more experienced lecturers to carry on teaching subjects than less experienced ones. Male instructors are also preferably chosen. Nonetheless, minor difficulties of those people as Internet connection and learning management system need addressing.

Education is more than just transforming knowledge from generation to generation. It is understood as a room for parties - teachers and learners - set up and study to set up their social relations (Dietrich, 2015). Desjean-Perrotta (2006) together with Janssen, Grossman, and Westbroek (2015) continue to reckon that only professional knowledge cannot make a person best fit with his teaching job; alternatively, a combination of both academic knowledge and interaction competence can. Nevertheless, this recommendation should be carefully revised amongst the university online teaching staff due to their distinguishable teaching experience. Longer seniority lecturers should experience more with technical support for their interaction with students in order to realize more positively about this communication channel's advantages. Apart from that, it will be a big mistake if online faculty managers define 'always available to students' as a remarkable supportive method e-teachers should produce. Alternatively, an impressive interaction behavior which management could nurture for online lecturers through technical support is possible provide individual care for each learner.

\section{Conclusion}

E-learning and educational technology have made universities more marketable to the community at large by offering online training programs (Dintoe, 2018). The mode of online 
teaching and learning has challenged both instructors and school management a lot not just in terms of workload increase (Dintoe, 2018; Jääskelä et al., 2017). To summarize, in an educational institution providing online teaching and learning process, management should give priority to understand their teachers in terms of psychological, cultural and social elements associated with technology. When lecturers hold positive beliefs of ICT, they are inclined to smoothly move to teach in a digital platform. Further research on technology love culture in higher education and characteristics of educators in such context should be conducted.

\section{References}

Adnan, M. (2017). Professional development in the transition to online teaching: The voice of entrant online instructors. ReCALL, 30(1), 88-111. doi:10.1017/S0958344017000106

Agbatogun, A. O. (2013). Interactive digital technologies' use in Southwest Nigerian universities. Education Technology Research Development, 61, 333-357. doi:10.1007/s11423-012-9282-1

Alt, D. (2018). Science teachers' conceptions of teaching and learning, ICT efficacy, ICT professional development and ICT practices enacted in their classrooms. Teaching and Teacher Education, 73, 141-150. doi:10.1016/j.tate.2018.03.02

Azlim, M., Amran, M., \& Rusli, M. R. (2015). Utilization of educational technology to enhance teaching practices: Case study of community college in Malaysia. Procedia - Social and Behavioral Sciences, 195, 1793-1797. doi:10.1016/j.sbspro.2015.06.385

Baran, E., Correia, A., \& Thompson, A. (2011). Transforming online teaching practice: Critical of the literature on the roles and competencies of online teachers. Distance Education, 32(3), 421-439. doi:10.1080/01587919.2011.610293

Claro, M., Salinas, A., Cabello-Hutt, T., Martín, E. S., Preiss, D. D., Valenzuela, S., \& Jara, I. (2018). Teaching in a Digital Environment (TIDE): Defining and measuring teachers' capacity to develop students' digital information and communication skills. Computers \& Education, 121, 162-174. doi:10.1016/j.compedu.2018.03.001

Copriady, J. (2015). Self-motivation as a mediator for teachers' readiness in applying ICT in teaching and learning. Procedia-Social and Behavioral Sciences, 176, 699-708. doi:10.1016/j.sbspro.2015.01.529

Crawford-Ferre, H. G., \& Wiest, L. R. (2012). Effective online instruction in higher education. The Quarterly Review of Distance Education, 13(1), 11-14.

Desjean-Perrotta, B. (2006). Developing a fitness to teach policy to address retention issues in teacher education. Childhood Education, 83(1), 23-28.

Dietrich, D. C. (2015). Observations of a reluctant online instructor: Transitioning from the classroom to the computer. College Teaching, 63, 93-98. doi:10.1080/87567555.2015.1019824 
Dintoe, S. S. (2018). Information and communication technology use in higher education: Perspectives from faculty. International Journal of Education and Development Using Information and Communication Technology, 14(2), 121-166.

Dintoe, S. S. (2018). Perspectives from faculty: A case study in University of Botswana. International Journal of Education and Development Using Information and Communication Technology, 14(1), 52-90.

Do, K., Fernando, M. S., \& Marrisa, C. L. (2018). Exploring 21st century teaching development model for lecturers: A case study of two universities in Vietnam. ABAC ODI Journal Vision. Action. Outcome, 5(2), 59-86.

Gomez-Rey, P., Fernández-Navarro, F., Barbera, E., \& Carbonero-Ruz, M. (2018). Understanding student evaluations of teaching in online learning. Assessment \& $\begin{array}{llll}\text { Evaluation in Higher } & \text { Education, 43(8), }\end{array}$ doi:10.1080/02602938.2018.1451483

González, C. (2012). The relationship between approaches to teaching, approaches to eteaching and perceptions of the teaching situation in relation to e-learning among higher education teachers. Instructional Science, 40(6), 975-998. doi:10.1007/s11251-0119198-x

Gonzalez, C. (2013). E-teaching in undergraduate university education and its relationship to approaches to teaching. Informatics in Education, 12(1), 81-92.

Hart, Z. P. (2014). Hybrid online teaching; Pathway to success for traditional universities. Kentucky Journal of Communication, 33(1), 40-51.

Haydn, T. A., \& Barton, R. (2007). Common needs and different agendas: How trainee teachers make progress in their ability to use ICT in subject teaching. Some lessons from the UK. Computer \& Education, 49, 1018-1036. doi:10.1016/j.compedu.2005.12.006

Hung, M., \& Chou, C. (2015). Students' perceptions of instructors' roles in blended and online: A comparative study. Computers \& Education, 81, 315-325. doi:10.1016.j.compedu.2014.10.022

Jääskelä, P. (2017). Teacher beliefs regarding learning, pedagogy, and the use of technology in higher education. Journal of Research on Technology in Education, 49(3-4), 198-211. doi:10.1080/15391523.2017.1343691

Jääskelä, P., Häkkinen, P., \& Rasku-Puttonen, H. (2017). Teacher beliefs regarding learning, pedagogy, and the use of technology in higher education. Journal of Research on Technology in Education, 49(3), 198-211. doi:10.1080/15391523.2017.1343691

Jamil, M., \& Shah, J. H. (2011). Technology: Its potential effects on teaching in higher education. New Horizons in Education, 59(1), 38-51.

Janssen, F., Grossman, P., \& Westbroek, H. (2015). Facilitating decomposition and recomposition in practice-based teacher education: The power of modularity. Teaching and Teacher Education, 51, 137-146. 
Jita, T. (2016). Pre-service teachers' competence to teach science through information and communication technologies in South Africa. Perspective in Education, 34(3), 15-26. doi:10.18820/2519593X/pie.v34i3.2

John, S. P. (2015). The integration of information technology in higher education: A study of faculty's attitude towards IT adoption in the teaching progress. Contaduría $y$ Administración, 60(S1), 230-252. doi:10.1016/j.cya.2015.08.004

Kihoza, P. D., Bada, J. K., \& Kalegele, K. (2016). An assessment of teachers' abilities to support blended learning implementation in Tanzanian secondary schools. Contemporary Educational Technology, 7(1), 60-84.

Kubrický, J., \& Č́stková, P. (2015). Teacher's competences for the use of web pages in teaching as a part of technical education teacher's ICT competences. Procedia-Social and Behavioral Sciences, 174, 3236-3242. doi:10.1016/j.sbspro.2015.01.988

Kumar, S., \& Daniel, B. K. (2016). Integration of learning technologies into teaching within Fijian Polytechnic Institutions. International Journal of Educational Technology in Higher Education, 13(36), 1-17. doi:10.1186/s41239-016-0036-8

Lachner, A., Jarozka, H., \& Nuckles, M. (2016). What makes an expert teacher: Investigating teachers' professional vision and discourse abilities. Instructional Science, 44(3), 197203. doi:10.1007/s11251-016-9376-y

Madsen, S. S., Thorvaldsen, S., \& Archard, S. (2018). Teacher educators' perceptions of working with digital technologies. Nordic Journal of Digital Literacy, 13(3), 177-196. doi:10.18261/issn.1891-943x-2018-03-04

Onivehu, A. O., Adegunju, A. K., Ohawuiro, E. O., \& Oyeniran, J. B. (2018). The relationship among information and communication technology utilization, self-regulated learning and academic performance of prospective teachers. Acta Didactica Napocensia, 11(1), 69-85. doi:10.24193/adn.11.1.6

Rose, E., \& Adams, C. (2014). Will I ever connect with the students: Online teaching and the pedagogy of care. Phenomenology \& Practice, 8(1), 5-16.

Safar, A. H., \& AlKhezzi, F. A. (n.d.). Beyond computer literacy: Technology integration and curriculum transformation. College Student Journal, 47(4), 614-626.

Schmidt, S. W., Hodge, E. M., \& Tschida, C. M. (2013). How university faculty members developed their online teaching skills. The Quarterly Review of Distance Education, 14(3), 131-140.

Shagrir, L. (2015). Working with students in higher education - Professional conceptions of teacher educators. Teaching in Higher Education, 20(8), 783-794. doi:10.1080/13562517.2015.1085854

Shattuck, J., \& Anderson, T. (2013). Using a design-based research study to identify principles for training instructors to teach online. The International Review of Research Open and Distance Learning, 14(5), 186-210. 
Valtonen, T., Kukkonen, J., Kontkanen, S., Sormunen, K., Dillon, P., \& Sointu, E. (2014). The impact of authentic learning experiences with ICT on pre-service teachers' intentions to use ICT for teaching and learning. Computers \& Education, 81(C), 49-58. doi:10.1016/j.compedu.2014.09.008

Wolf, P. D. (2006). Best practice in the training of faculty to teach online. Journal of Computing in Higher Education, 17(2), 47-48.

Zare-ee, A. (2011). University teachers' views on the use of information communication technologies in teaching and research. The Turkish Online Journal of Educational Technology, 10(3), 318-327.

Zhou, Z. (2018). An interaction theory-based new distance teaching model for cross talk. International Journal of Emerging Technologies in Learning, 13(6), doi:10.3991/ijet.v13i06.8588 